\title{
GEOMETRIAI VIZUALIZÁCIÓ A GYAKORLATBAN
}

\author{
Szerzők: \\ Tóth Attila \\ Konstantin Filozófus Egyetem \\ (Szlovákia) \\ Nagy Lehocky Zsuzsa \\ Konstantin Filozófus Egyetem \\ (Szlovákia) \\ Csáky Antal \\ Konstantin Filozófus Egyetem \\ (Szlovákia) \\ Sedlák Margaréta \\ Magán Szakközépiskola Diószeg \\ (Szlovákia) \\ Első szerző e-mail címe: \\ atoth2@ukf.sk
}

\section{Lektorok:}

\author{
Szabó Tibor \\ Konstantin Filozófus Egyetem \\ (Szlovákia) \\ Kmet'ová Mária \\ Konstantin Filozófus Egyetem \\ (Szlovákia)
}

és további két anonim lektor...

\begin{abstract}
Absztrakt
A tanulmányban bemutatunk néhány geometriai vizualizáció alapján létrejött diákmunkát. Javasoljuk, hogy a geometriai látásmód kialakítása során ötvözzük a hagyományos szerkesztéseket a számítógépes grafikai ábrázolásokkal, melyek által segíthetjük a tanulók síkbeli és téri tájékozódásának fejlődését. A tanulók divergens gondolkodása és kreativitása igazán a sajátos sakkfigurák tervezésénél bontakozott ki.
\end{abstract}

Kulcsszavak: Geometria, vizualizáció, térlátás, számítógépes programok

Diszciplína: matematika

\section{Abstract}

GEOMETRIC VISUALIZATION IN PRACTICE

The study presents some student works based on geometric visualizations. According to our experience, we recommend the combination of traditional constructions and 
computer graphic representations for students' progress in geometric vision, by which we can help the development of planar and spatial orientation. The divergent thinking and creativity of the students were truly unfolded in the design of specific chess pieces.

Keywords: Geometry, visualization, spatial vision, computer programs

Discipline: mathematics

Tóth Attila, Nagy Lehocky Zsuzsa, Csáky Antal és Sedlák Margaréta (2021): Geometriai vizualizáció a gyakorlatban. OxIPO - interdiszciplináris tudományos folyóirat, 2021/1, 83-95. doi: 10.35405/OXIPO.2021.1.83

\section{Bevezetés}

Az elmúlt évtizedekben tanúi lehetünk annak, hogy a matematika új fejezeteket nyitott meg és rátért egy újabb, könnyebb, de nem numerikus, hanem mértani megoldások útjára. Nemcsak a műszaki főiskolákon, hanem a közgazdasági szakokon is megjelentek azok a kihívások, miszerint mélyebb mértani tudásra és térlátásra van szükség. Hiszen a feltételes optimalizálásnál a kétismeretlenes egyenleteket helyettesíthetjük egyenesekkel, egyenlőtlenségeket félsíkokkal és ezek metszetével. A fö függvény egyenesével pedig megközelíthető az így nyert alakzat maximális (pl. nyereség), ill. kiadás és költség minimális pontja (Sydsaeter és Hammond, 2006; Fecenko és Sakálová, 2004; Fecenko és Pinda, 2006). Ez alapján új fejezetekkel kellene bővíteni a közép és általános iskolák matematika óráit. Annak ellenére, hogy alacsony a heti matematikaóraszám, a geometriát sem kellene elhanyagolni, hanem lehetőségeket kellene teremteni a geometriai - tapasztalat- szerzésre. (Menšík és Lanta, 1964). Az ötödik osztálytól kezdve megismerkedhetnének a gyerekek az alakzatok vizualizációjával, részeiben és mozgásában pedig ennek a felhasználásával az építészetben. Vonalakkal, síkokkal behatárolt felületeket rajzolhatnának, és ezekre támaszkodva kellene megszerkeszteniük a látható világ alakjait. A hatodik osztályosok már megismerkedhetnének a fényképészet elemeivel, az analóg és digitális képekkel, a színek kontrasztjával, a kicsinyítéssel és nagyítással. E tanulmányban ismertetjük azokat a tapasztalati eredményeket, melyeket sikerült elérni a középés főiskolákon a geometriai vizualizáció segítségével, továbbá bemutatjuk, hogy hogyan sikerült fejleszteni a síkban és térben való orientálódást.

A korábbi évtizedekben megfigyelhető volt az iskoláinkban, hogy megjelentek bizonyos tanulási nehézségek, és általában a matematikához való viszony is romlott (Maczák, 2016; SRPSZKK, 2020; Šveda, et al. 2019). Sokan nem képesek elsajátí- 
tani és alkalmazni a matematikai szimbólumokat (a számokat és a múveleti jeleket), a grafikus feladatok értelmezésére pedig helyenként képtelenek. Gyengék az elemző, egységesítő és összehasonlító képességek, emellett általában a geometriai vizualizáció is gondot okoz. Ezért is tartjuk fontosnak, hogy beszámoljunk jó gyakorlatainkról, konkrétan arról, hogy hogyan és mivel sikerült felkelteni a felnövekvő generáció érdeklődését a geometria terén.

A geometria oktatásának esetében az OxIPO-modell a következőképpen értelmezhető: a tanulóknak adott szöveges és/vagy képi inputok kognitív feldolgozása (process) eredményeképpen jön létre az a többnyire vizuális (de szavakkal is körülírható) output, amit egy-egy feladat megoldásának tekinthetünk. A tanulás/tanításszervezés (organizáció) pedig végigkíséri a feladatadásának, a megoldáshoz vezető műveletek végzésének, és az output előállításának és ellenőrzésének, valamint a tanulónak szóló visszajelzésnek (például fejlesztő értékelésnek) a módszertani folyamatát.

\section{A térgeometriától az anaglif képekig}

A geometriai ismeretek és a megfelelő szintű térlátás elengedhetetlenül fontos lenne a jövő nemzedék számára, és nemcsak a mûszaki beállítottságú szakemberek, hanem a közgazdasági, valamint az ehhez kapcsolódó rokon szakok esetében is. A nyolcvanas évek végéig ez nem okozott ekkora problémát, hiszen már az általános iskolákban is volt ábrázoló mértan. Erre kapcsolódott a középiskolákban az ábrázoló geometria (Menšík és Lanta, 1964). Ezek a tantárgyak megalapozták a geometriai térlátást, a merőleges vetítések és a párhuzamosokkal való ábrázolás megfelelő alapokkal látták el a diákokat (Fatková, 1966).

$\mathrm{Az}$ ábrázoló geometria segítségével megoldhatónak bizonyul a térbeli feladvány is, hiszen tanultak axonometriát, metszeteket, párhuzamos vetítéseket (Fatková, 1966). A műszaki jellegű középiskolákban erre épülhetett a műszaki rajz. Az előző generációk térlátását tehát segítette a piros-zöld szemüveggel kialakított ún. ábrázoló mértan. A szem geometriájára alapozva úgy látszanak az alakzatok, mintha azok térbeliek lennének. Ezt mutatja be Pál Imre fantasztikus könyve, amely 1959 óta több kiadásban is megjelent (Pál, 1960; Pál, 1973). A mai modern világban ennek a hagyományos módszernek a megismer-tetését tűztük ki célul az általános és középiskolákban.

Miután bemutattuk a síkelemeket, térelemeket és görbe felüle-teket, a tanulóknak arra kellett rájönniük, miért nem jön elő a térben az 1. ábrán látható két szélső kocka, amit rajzoló program segítségével rajzoltunk és miért is látható a térbeli hatás a középső, kézzel, pontosan rajzolt kocka esetében. 
1. ábra: A kocka és vetületeinek rajzai különbözó vetitésekkel (Forrás: bal oldali képek tanulói munka Magán Szakeközépiskola, Diószeg, jobb oldali kép Kmet’ová, Vitézová, 2015)
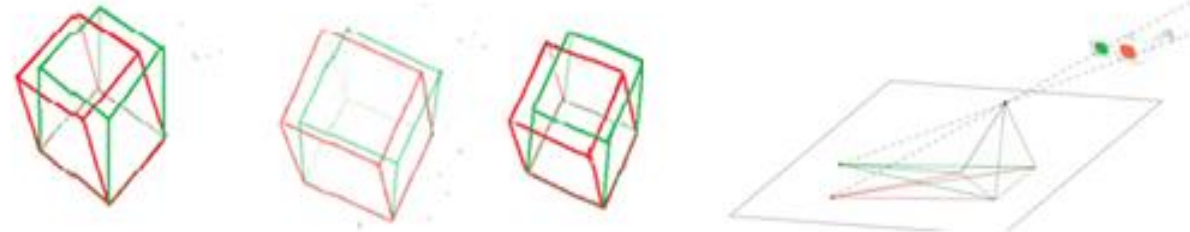

A középiskolában végzett kutatás során megállapíthattuk, hogy nagyon kevesen jöttek rá a „mutatvány” titkára. A titok egész egyszerűen a középpontos vetítés (1. ábra jobb oldalon: a szemtávolság 6,5 $\mathrm{cm})$. Nem mindegy ugyanis, hogy milyen színű a fô ábra, és melyik a vetület, hiszen ennek a függvényében kell a jobb, vagy bal szemre helyezni a zöld szemüveget. Arra is rá kellett jönniük, hogy például a közismert Microsoft Paint programban megrajzolt egyenesek nem tökéletes egyenesek, hiszen pontszerűen a tengelyekkel párhuzamosan lehet csak rajzoltatni. Természetesen csak akkor van gond, ha e célból vektoros rajzoló program nem áll a rendelkezésre. Nagyobb nagyításnál látható a képfelbontás minősége alapján, hogy vízszintes illetve függőleges szakaszocskákból tevődik össze a ferde vonal. Így, ha ebben a programban szeretnénk térbeli hatásokat elérni, akkor nagy nagyításban nagyon vékony vonalakat kell húzni, majd ugyanezt kicsinyíteni, hogy a ferde szakaszok „eltűnjenek”. A felsőbb tagozatos osztályoknál észrevettük, hogy nagyon pontos rajzolásra és szerkesztésre van szükség. Valamint a színek megválasztásánál is kell vigyázni, hogy ne árnyalata legyen a szemüveg színe a rajzolt színnek, hanem ha lehet, ugyanolyan hullámhosszú (színú) kell, hogy legyen, hiszen csakis így válik sötét színűvé. Az ilyen jellegű tapasztalatok alapozzák meg azt a tudást, amit a későbbiekben kell elsajátítani a számítógépes grafikusoknak is.

A középiskolás digitális média grafikus szakon szintén bemutattuk ezt a típusú geometriát. A diákoknak többek között az volt a feladatuk, hogy a diószegi műemlékjellegű iskola épületét fényképezzék le, majd próbálják meg egy számítógépes program segítségével a felvétel két (piros és zöld) árnyalatát eltolni egymáshoz képest. További feladatként az interneten anaglif képeket kellett tanulmányozniuk a megadott jelszavak alapján (Kmet'ová és Vitézová, 2015). A legjobban azonban az önarcképek sikerültek. Egy másodikos középiskolásnak sikerült térhatást elérnie a „szelfijével” (lásd: 2. ábra). 
2. ábra: Egy önarckép (Forrás: Magán Szakközépiskola, Diószeg)

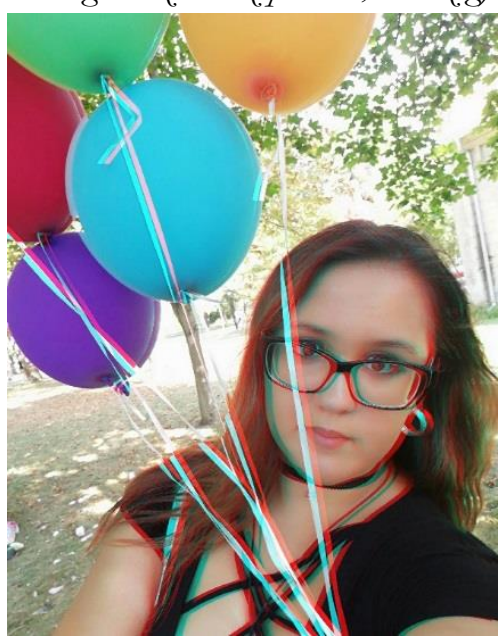

Az általános iskolásokkal a térláttató geometriát egyszerű rajzok segítségével gyakoroltuk, konkrétan virágmintákkal, ahol helyenként megmutatkozott a térbeli hatás (lásd: 3. ábra).

A meghosszabbodott pandémia alatt kapták feladatul azt is, hogy az iskoláról készült korábbi képekből igyekezzenek térbeli hatást kihozni, ami a 4. ábrán 3D szemüveggel jól látható.

Valószínúleg az iskola és a barátok hiánya okozta azt, hogy megalkották a világjárvány „tette-sének” térbeli képét is, ami viszont csak a kétszínű szemüvegen keresztül látható.

3. ábra: Egy elemi iskolás próbarajzai (Forrás: tanulói munka Alapiskola, Diószeg)
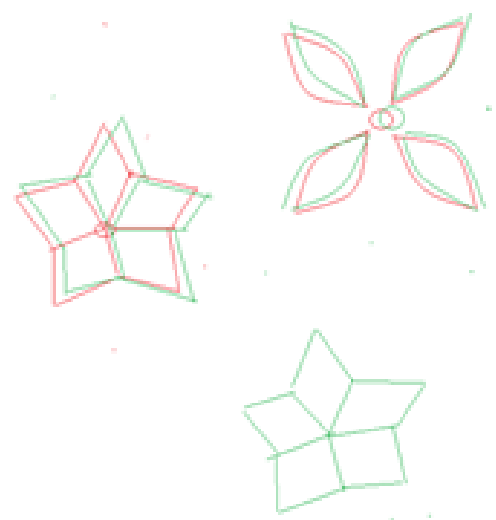


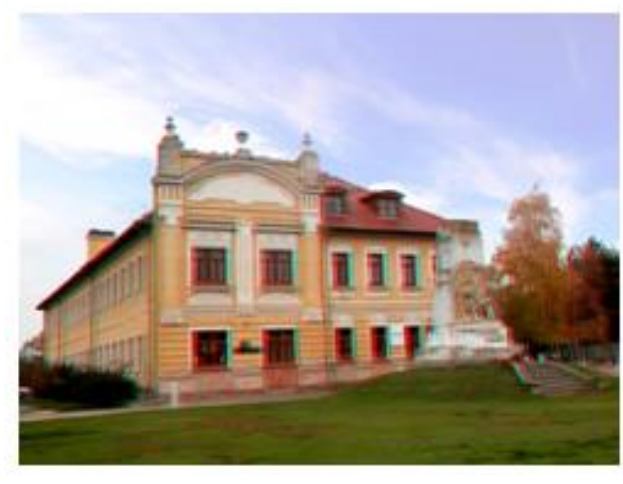

\section{Gyakorlati tapasztalatok}

Igyekeztünk leírni a több évtizedes tapasztalatot, amely megmutatta, hogy az informatikában, a gépészetben és a média grafikus szakok tervezeteiben nagy a különbség, viszont ugyanaz a cél: fejleszteni a síkbeli elképzeléseket és térbeli látást. A gépészeknél sokat segítettek a térbeli alakzatok, makettek. A gyakorlatban alkalmazott térbeli testeket világítottunk meg a sötétkamarában, a hasábokat, félhengereket, a kúpot és azok csonka darabjait. Így vált szemléletessé az alaplapra, hátlapra és oldallapra szórt árnyék vetület. Majd egyre bonyolultabb alakzatokat rajzoltattunk, ekkor már a „lelki szemeikkel" kellett elképzelniük a vetületeket. A következő lépés pedig az volt, hogy a vetületekből kellett felrajzolni a valós alakzatot, pl. oldalnézetből. Ez a hagyományos eszközhasználat sokat fejlesztett a képzeteken. Ugyanakkor azt is tapasztaltuk, hogy ha mindezt egy program segítségével csináljuk, akkor az agy ellustul. Automatikusan ráhagyatko-

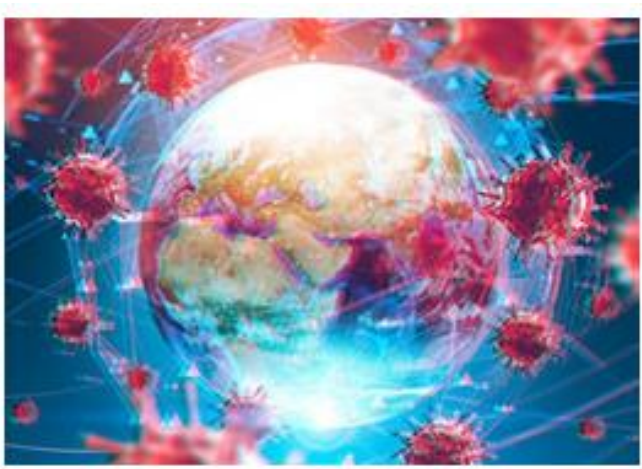

zunk a gép tévedhetetlenségére, hiszen a forgatás is elvégeztethető a programok segítségével. Miért nem elegendő csak a virtuális ismeret? Mert csakis kézzelfogható, saját rajzokkal jöhetünk rá olyan összefüggésekre, mint például arra, hogy a szakasz vetületeinek a méreteiből rá kell tudni jönni arra, hogy mekkora volt a szakasz eredeti nagysága. Ennélfogva bizonyos szintig a hagyományos módszerek használata ma is nagyon fontos lenne. A henger metszeteinek alapos ismeretei alapján jobban kivitelezhetők a légkondicionálás és fütés vezetékei, hiszen a hengermetszetek összeillesztéséről szól. Hagyományos módon kellene lerakni a kinematikus geometria alapjait is, a körön mozgó pont vetületei és magassága oly sok ciklois, asztroid, kardioid és spirálisok, valamint egyéb szimmetriák könnyebben válnak érthetőbbé.

A valós ábrázolást ajánlatos nem kihagyni, mert a tapasztalatok azt mutatják, hogy a felnövő nemzedék nem kapcsolja össze a virtuális világot a való világgal. A 
számítógépes programok megjelenése előtt először laboratóriumi, majd kistermelési szinten, végül pedig ezek alapján lehetett kipróbálni a rajz pontosságát, illetve pontatlanságát nagyüzemi módban. $\mathrm{Az}$ ezredfordulón jelentek meg azok a szimulációk, amelyek segítségével már egy - egy köztes lépés kihagyható volt. Megoldás lenne, ha minden esetben ötvöznénk a hagyományos szerkesztéseket a számítógépes grafikai ábrázolásokkal. Ezek segítségével ösztönözni lehet a kreativitást, az önálló gondolkodás fejlesztését, az ebből következő vitát, érvelést, logikai és matematikai számítást.

Megdöbbentő tapasztalat, hogy a tanúlók geometriai tudása rendkívül hiányos, hiszen sokan például a kör és a gömb köz- ti különbséget sem tudják jellemezni, vagyis az alapvető fogalmakkal sincsenek tisztában, hogy mi a sugár, az átmérő, vagy a húr. A felszín és térfogat közötti különbség megfogalmazása is gondot okoz. Pedig csupán a négyzet és a kocka közötti különbségekkel érthetik meg a síkbeli és térbeli alakzatokat. Véleményünk szerint ez kiküszöbölhető lenne, csupán több figyelmet kellene fordítani már általános iskolában a geometriai tapasztalatszerzésre.

$\mathrm{Az}$ 1. táblázat segítségével foglaltuk össze tapasztalatainkat, ahol három csoportot alkotnak a feladatmegoldók, akik ugyanazokat a feladatokat kapták a végeredmény mégis különbségeket tükröz (lásd: 1. táblázat):

\section{1. táblázat: A feladatokhoz különböző módon állnak hozzá a tanulók (forrás: a Szerzó)}

\begin{tabular}{|c|c|c|c|}
\hline Csop. & Besorolás & Feladat megadás & Végeredmény \\
\hline 1. & $\begin{array}{l}\text { Egyéni munka, } \\
\text { csalás/plagizálás }\end{array}$ & $\begin{array}{l}\text { Feladat megadása, majd egyé- } \\
\text { ni munka odahaza. }\end{array}$ & $\begin{array}{l}\text { A diákok többségének felüle- } \\
\text { tes a hozzáállása. Az új infor- } \\
\text { mációk befogadására képte- } \\
\text { lenek. }\end{array}$ \\
\hline 2. & $\begin{array}{c}\text { Figyelemmel kísért } \\
\text { munka }\end{array}$ & $\begin{array}{l}\text { Feladat megadása, szabályok } \\
\text { felállítása. Figyelemmel kísért } \\
\text { munka, melyet folyamatosan } \\
\text { ellenőriz egy hozzáértő sze- } \\
\text { mély, vezeti a feladat megol- } \\
\text { dásában a hallgatót. }\end{array}$ & $\begin{array}{l}\text { Feszültebb a figyelem, így } \\
\text { rákényszerül a hallgató, hogy } \\
\text { a hiányosságokat pótolja. A } \\
\text { munka, időre elkészül, viszont } \\
\text { a hallgatóban megmarad a } \\
\text { félelem, a stressz. }\end{array}$ \\
\hline 3. & Motivált tanulók & $\begin{array}{l}\text { Feladat megadása motiváció- } \\
\text { val. }\end{array}$ & $\begin{array}{l}\text { A hallgató időre elvégzi a } \\
\text { feladatát, belső motivációtól } \\
\text { vezérelve ösztönzi önmagát a } \\
\text { további gyors és eredményes } \\
\text { lépésekre. Mindig új ötletek- } \\
\text { kel áll elő. Együttmúködik. } \\
\text { Alaposabb kutatást végez az } \\
\text { adott területen. Eredményét } \\
\text { elismeréssel fogadják. }\end{array}$ \\
\hline
\end{tabular}


Először minden esetben pótolni kell a hiányosságokat és csak azután sajátítható el az egyes programok kezelése. Mind a programok kezelését illetően, mind a feladatok megadásánál a fokozatoságra kell törekedni. Végül olyan feladatokat is adhatunk, melyekben hibákat rejtünk el (lásd: 6. ábra).

A matematikában, informatikában és a gépészeten belül, mint gyártási folyamatokban, tökéletesen hasznát vehetjük különböző 2D-s és 3D-s programoknak, melyek napjainkban lényegesen megkönnyítik a grafikusok, mérnökök ezreinek munkáját. Már a középiskolában megismerhetik a grafikán belül a CorelDRAW, Inkscape vagy Abode Photoshop programokat, a gépészeknek pedig átvezethető grafikus szintre is a Solid Edge 2D/3D CAD tervező szoftver program. Az összes program kezeléséhez szükséges az angol nyelv ismerte, a matematika és azon belül is a geometriai ismeretek. A Siemens PLM Software által fejlesztett Solid Edge egy nagy teljesítményű 3D-s CADszoftver
(SOVA DIGITAL 2020), mely a diószegi iskolában is használt programcsomag része (lásd: 2. táblázat).

A feladatokat a tanulókkal közösen alkottuk meg, lépésről lépésre. A megoldást viszont már önállóan kellett elkészíteniük. Figyelemmel kísértük a tanulók megfigyelő képességét, gondolatmenetét és problémamegoldását.

Mivel a mai informatikai grafikai szerkesztő programok állandó fejlesztés alatt állnak, így a sokéves tapasztalatokra támaszkodva a fejlesztők olyan ergonomikus programkörnyezeteket hoztak létre a felhasználók számára, melyeket testre szabhatnak és így - felhasználó-barátabbá tehetnek. Ezért is fogadták szívesen a tanulók, hogy a program meg tudja fordítani az alkatrészeket úgy, hogy az egyes nézetek által leolvashatóvá válnak a méretek (lásd: 5. ábra, v.ö.. 6-8. ábrák).

Ezen programok múködési elveinek köszönhetően viszont fel kellett ismernünk, hogy a tanulóknál évről-évre romlik a térbeli tájékozódás képessége.

2. táblázat: A Solid Edge programcsomag részei (forrás: a Sžerzô)

\begin{tabular}{|l|l|}
\hline Programrész megnevezése & \multicolumn{1}{c|}{ Programrész leírása } \\
\hline Alkatrész & Megtalálható a 2D/3D tervezés. \\
\hline Lemezalkatrész & Megoldhatók a pléhhajlításra vonatkozó megoldások. \\
\hline Összeállitás & $\begin{array}{l}\text { Lényegesen megkönnyíti a tervezó számára az összes } \\
\text { megtervezett alkatrész összeszerelését egy egésszé. }\end{array}$ \\
\hline Mühelyrajz & $\begin{array}{l}\text { Az alkatrész tervező részből egyszerú módon átvihető a } \\
\text { 3D-s kész alkatrész műszaki formátumba, melyen a } \\
\text { megfelelő végleges műszaki rajz pár adat hozzáadásával } \\
\text { kivitelezhető rövid időn belül. }\end{array}$ \\
\hline Tartószerkezet tervezés & Konkrét hegesztett alkatrészek tervezése. \\
\hline
\end{tabular}


5 .ábra: Egy egysz̨erü alkatrész, alul, felül és oldalnézete, méretmegadás (Forrás: a Szuerző))

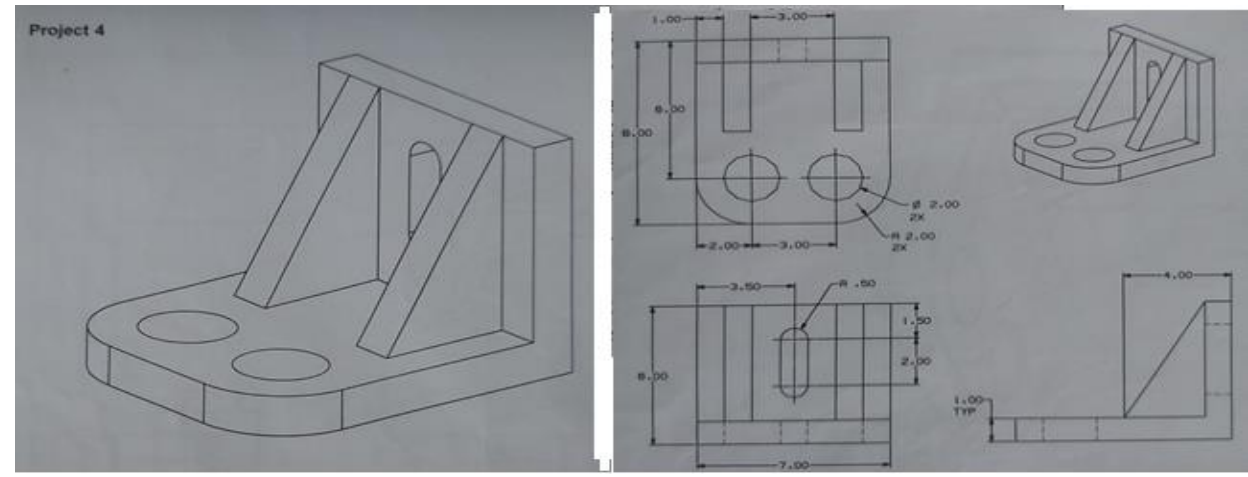

6. ábra: Bonyolultabb feladat rejtett hibákekal (Forrás:a Szerző́)

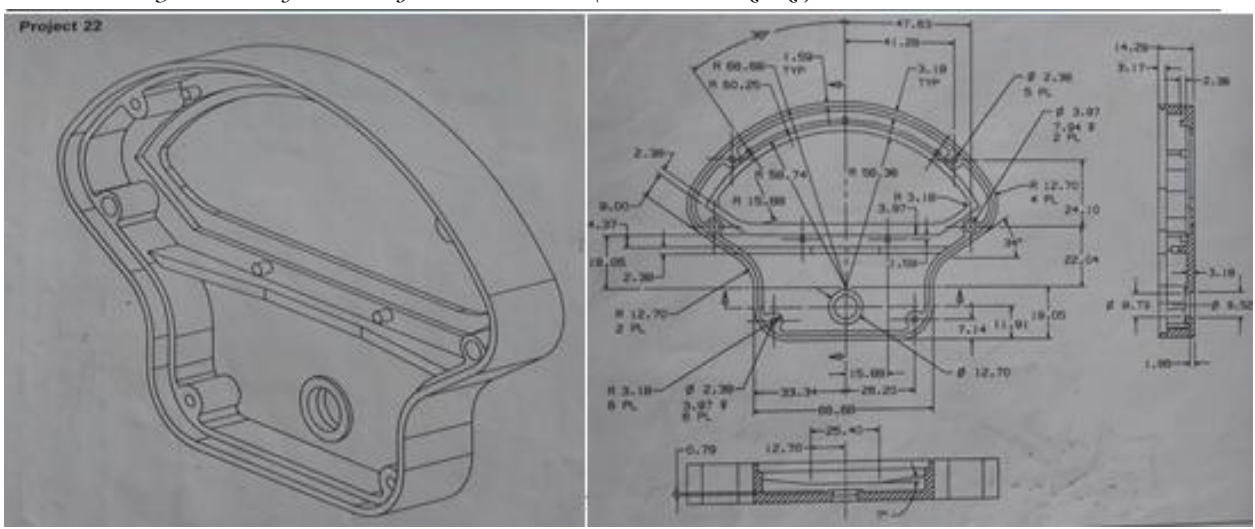

7. ábra: Diákok által készitett 3D-s feladatok, egy forgatható fogaskerék és egy vek.keróra. (Forrás: Magán Sakeközépiskola, Diószeg)

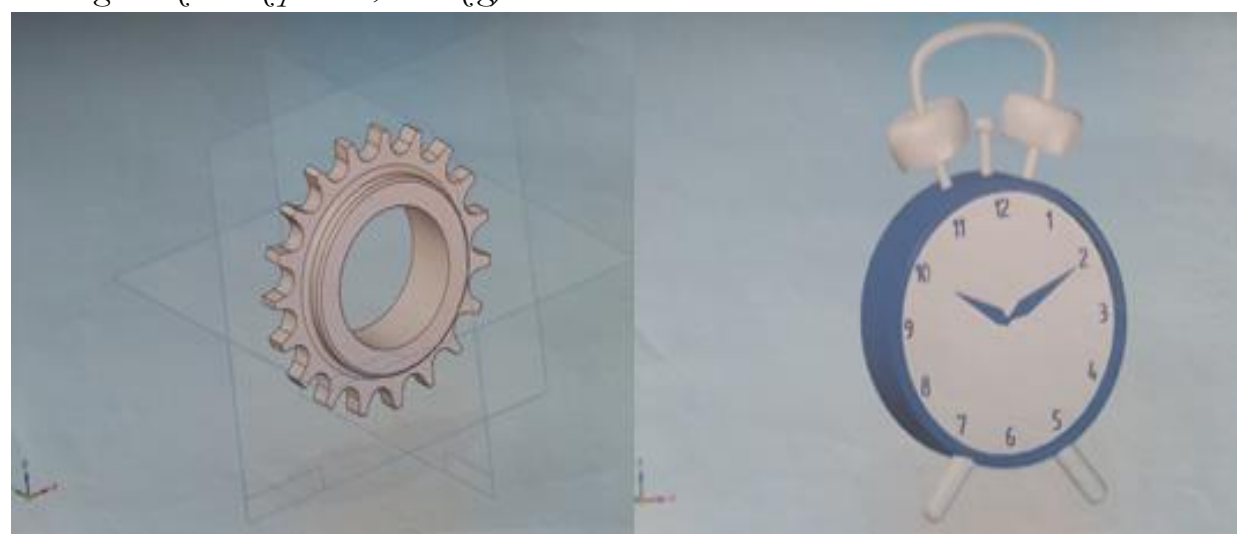



A program fejlesztői lehetôvé tették, hogy együtt tovább fejlesszük azt. Így kerülhetett sor arra, hogy megtervezhettük a laza, az átmeneti és merev illesztéseket. Ezáltal lehetővé vált szimulációban kipróbálni, hogy az adott tűréshatárral megtervezett alkatrész mozogni fog-e, vagy sem. Tehát egy autókerék tervezésénél egy adott illesztéssel ellátott kerék felrakva pörögni kezd-e - mert meg lehet forgatni, a vagy a biciklikerék a váz rámájának villájába beültetve kicserélhető lesz-e.

Végül egy egyszerűnek tűnő, de bonyolult feladatot is kaptak a diákok: egy sakktáblát kellett megtervezniük, úgy, hogy nem kaptak semmilyen további adatot a kivitelezéshez.
A következőket kellett teljesíteniük:

1. A nehézség abban rejlett, hogy először létre kellett hozniuk a sakkfigurákat, azaz meg kellett azt tervezniük. Szabad kezet kaptak, ami a formai kivitelezést illeti. Ügyelniük kellett viszont a sakkfigurák méretarányainak betartására, hogy a sakktáblára elférjenek.

2. Utána létre kellett hozniuk magát a sakktáblát. Szintén a méretarány a fontos, hiszen erre kerültek rá a sakkfigurák.

3. Végül a program összeszerelési részében egyesíteni kell az összes figurát a sakktáblán. A 9. ábra mutatja a végeredményt az egyik középiskolás elsős diáktól.

9. ábra: Külön-külön a sakkfigurák megtervezése forgatással, majd egy összeszerelt sakektábla az. összes, de nem forgatással készü̈lt figurái (Forrás: Magán S zakközépiskola, Diószeg)
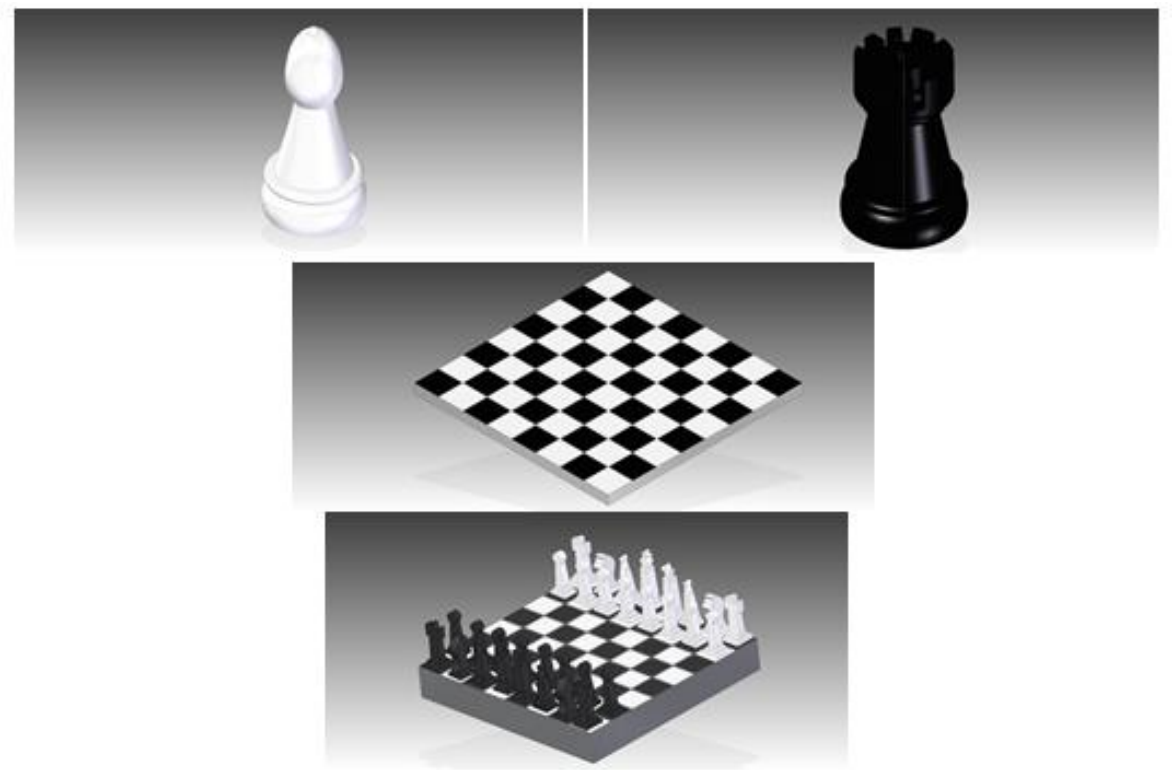
A diákok minden feladaton kitartóan, szorgalommal és igyekezettel dolgoztak. A felmerülő problémák megoldásakor megmutatkozott problémamegoldó gondolkodásuk, kreativitásuk és leleményességük. A végeredménynek együtt örülhettünk, hiszen hosszú gondolkodás, többszöri illesztés és sok kis apró lépés után volt összerakható egy szerkezet. A méretarányokat eltalálták, a szín kombinációkat tudták használni, kreatív volt a formai kivitelezés, és az összeszerelési részben a koordináció is megfelelt. Sajnos azonban ezt tíz diákból maximum kettő tudta gond nélkül kivitelezni a tervezéssel együtt. Az előzőekben szemléltetett 3D-s feladatoknál a legtöbb gond a térben lévő koordinációval volt, főleg, ha úgy kapták meg a feladatot, hogy konkrét adatok is voltak megadva.

\section{Konklúzió}

Bemutattunk néhány olyan geometriai eszközt, melyek segítik a tanulók geometriai ismereteinek megszerzését. Hiszen már nemcsak a gépészeknél, a média grafikus szakokon, hanem egyre több ágazatban megjelenik a térszemléletet fejlesztô geometria fontossága. Rámutattunk arra is, hogy könnyebb geometriai úton megtalálni egy-egy geometriai feladat eredményét. Tapasztalataink alapján arra kell ösztönöznünk a diákokat, hogy ne csak a virtuális térben gondolkodjanak, hanem próbálkozzanak adott alakzatokat és mozgásokat papíralapon is megrajzolni és maketteket készíteni, hiszen minden megvalósítás más jellegű tapasztalatot biztosít. Célunk volt, hogy megszerettessük a diákokkal a térgeometriát, fejlesszük a síkbeli és térbeli orientációjukat, tökéletesítsük térlátásukat. Fontos, hogy helyesen értelmezzék a grafikai feladatokat, hogy a szakgyakorlatokon elsajátított tapasztalataikat majd a munkahelyeiken is alkalmazni tudják.

\section{Köszönetnyilvánitás}

A tanulmány a KEGA 015UKF-4/2020 Development spatial abilities of 10-12year-old students projekt segítségével jött létre.

\section{Irodalom}

Fatková, E. (1966). Ábrázoló geometria középiskolásoknak (2. és 3 osztály). Bratislava: SPN.

Fecenko, J. és Pinda, L. (2006). Matematika 1. Bratislava: Iura Edition.

Fecenko, J. és Sakálová, K. (2004). Matematika 2. Bratislava: Iura Edition.

Kmet'ová, M. és Vitézová, Z. (2015). Anaglyfy a ich využitie vo vyučovaní geometrie. Slovenský časopis pre geometriu a grafiku 12(23).31-36.

Maczák, I. (2016). A matematikában botorkáló gyerekek - kérdések és válaszok a diszkalkuliáról. Új Köznevelés 72(8). 38-41

Menšík, M. \& Lanta, O. (1964). Ábrázoló geometria az általános müveltséget nyújtó középiskolák 2. évfolyama számára. Bratislava: Slovenské pedagogické nakladatel'stvo. 
Pál, I. (1960). Deskirptivna geometria videná priestorove. Budapest: Műszaki Könyvkiadó.

Pál I. (1973). Térgeometria a müszaki gyakorlatban. Budapest: Tankönyvkiadó.

SOVA DIGITAL. (2020) Solid edge pre použivatelov. https://sova.sk/prepouzivatelov/solid-edge-pre-

pouzivatelov/ (letöltve: 2020.5.13)

Sydsaeter, K. és Hammond, P.I. (2006). Matematika közgazdászoknak. Budapest: Aula.
Šedivý, O. (1990). Cviičenia z. geometrie a konstrukénej geometria. Nitra: UKF. Šveda, D. és Repovský, M. és Ftáčik, M. (2019). Matematické vzdelávanie zmeny pre budúcnost'. http://www.ruzsr.sk/app/webroot/C msPlugin/files/Prezentacia z konfere ncie Matematicke vzdelavanie zmeny _pre buducnos - 2. 4.2019.pdf (letöltve: 2020.9.15) 